\title{
The influence of extrusion of faba bean seeds and supplementation of sulphur amino acids on performance, pancreatic trypsin activity, and morphological parameters of the jejunum in rats
}

\author{
M. Leontowicz ${ }^{1}$, H. Leontowicz ${ }^{1}$, M. Biernat ${ }^{2}$, M.A. Gralak', \\ H. Kostyra ${ }^{3}$ and J. Czerwiński ${ }^{1}$
}

'Department of Physiology, Biochemistry, Pharmacology and Toxicology,

${ }^{2}$ Department of Anatomy, Histology and Embryology, Faculty of Veterinary Medicine,

Warsaw Agricultural University

Nowoursynowska 166, 02-787 Warszawa, Poland

${ }^{3}$ Division of Food Science, Institute of Animal Reproduction and Food Research,

Polish Academy of Sciences

Tuwima 10, 10-7/8 Olsztyn. Poland

\begin{abstract}
The effect of extrusion of faba bean seeds and supplementation of sulphur amino acids (AA) on trypsin inhibitor (TI) and lectin activity, and the histology and microbiology of the jejunum were studied. Male Wistar rats were fed semi-purified diets containing $10 \%$ faba bean seeds, either raw $(\mathrm{R})$ or extruded at $160^{\circ} \mathrm{C}(\mathrm{E})$; the diets were either unsupplemented or supplemented with $0.3 \%$ sulphur AA (met + cys, 1:1). Extrusion reduced TI activity of seeds from 1.8 (FR) to 0.5 with TIU/mg (FE) and completely eliminated agglutination activity against human red blood cells (RBC). Extrusion of faba bean seeds did not affect rat performance or pancreatic trypsin activity ( $5255 \mathrm{vs} 4065 \mathrm{U} /$ $100 \mathrm{~g}$ protein), and decreased $(\mathrm{P}<0.05)$ dry matter digestibility $(89.7 \mathrm{vs} 92.9 \%)$. Supplementing sulphur amino acids improved performance of rats fed both raw and extruded seeds. Extrusion of faba bean and supplementing sulphur amino acids significantly improved intestinal crypt depth, villi length and width.
\end{abstract}

KEY WORDS: lectins, trypsin inhibitors, extrusion, methionine, cystine, faba bean, rat

\section{INTRODUCTION}

Although faba bean seeds have fewer protease inhibitors and lower lectin activity than soyabean seeds (Valdebouze et al., 1980; Leontowicz et al., 2001b), 
they contain tannins, which reduce digestibility by forming complexes with protcins and/or digestive enzymes (Griffiths and Moseley, 1980) and also depress animal performance. Different technologies (boiling, autoclaving, extrusion) are used for inactivation of thermolabile ANFs present in legumes (Licner, 1994). The low level of sulphur amino acids limits growth of animals fed on diets with legumes but supplementation with synthetic amino acids usually improves performance.

The aim of our study on rats was to estimate the effect of extruding faba bean seeds and supplementing sulphur amino acids on performance, protein digestibility, pancreatic trypsin activity, morphometry of the jejunal mucosa, and total counts of bacteria colonizing mucosa.

\section{MATERIAL AND METHODS}

\section{Animals and diets}

Male Wistar rats of about $86 \pm 7 \mathrm{~g}$ were divided into four groups of ten and fed, ad libitum, for 28 days semi-purified diets composed of $(\%)$ wheat starch, 64.3; casein, 10; cellulose, 1 ; soyabean oil, 10; mineral-vitamin mixture, 4.7 (NAS, 1972) and $10 \%$ faba bean seeds (Vicia faba L.) var. Nadwiślański (F), raw (R) or extruded (E) (extruder INSTA-PR0 600, temp. $160^{\circ} \mathrm{C}$, exposition time $30-60 \mathrm{~s}$ ). Half of each diet was supplemented with $0.3 \%$ sulphur amino acids (AA) (met + cys, $1: 1$ ). Digestibility of dry matter and protein were estimated.

\section{Measurements}

Trypsin inhibitor activity (TIA) in the seeds was analyzed according to Valdebouze et al. (1980). Pancreatic trypsin activity (Erlanger et al., 1961) and protein content (Lowry et al., 1951) were determined.

Lectins were extracted from raw and extruded seeds according to Paredes-Lopez et al. (1989) and the agglutination test with human RBC (groups O, A, B, AB) was performed according to Liener (1989).

In the jejunum, the depth of crypts, length and width of villi, and thickness of the tunica mucosa were measured and total bacteria and $E$. coli counts were determined (except group FE) as described in a previous paper (Leontowicz et al., 2001a).

\section{Statistical analysis}

The results were evaluated by ANOVA and differences between arithmetic means $(x \pm S D)$ were evaluated by the Tukey multiple range test. 


\section{RESULTS}

Trypsin inhibitor activity in faba bean seeds was reduced by extrusion from 1.8 to $0.5 \mathrm{TIU} / \mathrm{mg}$ (Table 1). The lectin extract obtained from raw seeds agglutinated human red blood cells without a clear-cut affinity for a specific blood group; the smallest activity was found against group B (Table 2). Extrusion eliminated hemagglutination activity.

TABLE 1

Trypsin inhibitors and haemagglutination titre of protein extract from faba bean sceds

\begin{tabular}{lccccc}
\hline \multirow{2}{*}{$\begin{array}{l}\text { Faba bean } \\
\text { seeds }\end{array}$} & $\begin{array}{c}\text { Trypsin inhibitors, } \\
\text { TIU/mg }\end{array}$ & \multicolumn{4}{c}{ Haemagglutination titre of human red blood cells } \\
\cline { 2 - 6 } & & $\mathrm{O}$ & $\mathrm{A}$ & $\mathrm{B}$ & $\mathrm{AB}$ \\
\hline Raw & 1.8 & $1: 200$ & $1: 100$ & $1: 50$ & $1: 200$ \\
Extruded & 0.5 & 0 & 0 & 0 & 0 \\
\hline
\end{tabular}

$\mathrm{O}=$ no agglutination at $1 \mathrm{mg} / \mathrm{ml}$ concentration of initial protein extract,

$1: 50,1: 100,1: 200$ - dilution of initial $(1 \mathrm{mg} / \mathrm{ml})$ protein extract

TABLE 2

The influence of faba bean extrusion and sulphur amino acids supplementation on performance, dry matter and protein digestibility in rats $(\mathrm{n}=10)$

\begin{tabular}{lcrrr}
\hline Itcm & Dict FR' & Dict FE & Dict FRAA & Dict FEAA \\
\hline Food intake, g/d & $11.3 \pm 1.6^{\mathrm{a}}$ & $11.9 \pm 1.8^{\mathrm{a}}$ & $14.5 \pm 1.3^{\mathrm{b}}$ & $15.9 \pm 1.5^{\mathrm{b}}$ \\
Body gain, g/d & $2.7 \pm 0.4^{\mathrm{a}}$ & $3.0 \pm 0.5^{\mathrm{a}}$ & $5.2 \pm 0.8^{\mathrm{b}}$ & $5.6 \pm 0.8^{\mathrm{b}}$ \\
Feed/gain, g & $4.0 \pm 1.2^{\mathrm{b}}$ & $4.0 \pm 0.3^{\mathrm{b}}$ & $2.8 \pm 0.2^{\mathrm{a}}$ & $2.9 \pm 0.3^{\mathrm{b}}$ \\
& & & & \\
Digestibility, \% & & & & \\
$\quad$ dry matter & $92.9 \pm 1.5^{\mathrm{b}}$ & $89.7 \pm 2.0^{\mathrm{a}}$ & $92.7 \pm 0.9^{\mathrm{b}}$ & $92.8 \pm 0.9^{\mathrm{b}}$ \\
crude protein & $85.0 \pm 2.9$ & $86.0 \pm 1.1$ & $85.2 \pm 2.1$ & $85.5 \pm 2.2$ \\
\hline
\end{tabular}

a,b.c means in the rows tagged with different letters differ significantly at $\mathrm{P}<0.05$

1 faba bean raw

2 faba bean extruded

3 faba bean row tamino acids

4 faba been extruded + amino acids

The protein content in the diets amounted to: $12.12 ; 12.15 ; 12.77 ; 12.59 \%$ on a DM basis in FR, FE, FRAA and FEAA, respectively. Extrusion of faba bean seeds did not affect feed intake, body gain, or FER (Table 2). Sulphur AA supplementation of diets with raw and extruded seeds significantly improved 
performance. Dry matter $(\mathrm{DM})$ digestibility was lower $(\mathrm{P}<0.05)$ in rats fed $\mathrm{FE}$ than FR (89.7 vs 92.9), AA supplementation significantly increased DM digestibility in FEAA. Crude protein digestibility was not affected by either extrusion or AA supplementation.

The proteolytic activity in the pancreas tended to be higher in rats fed extruded beans (Table 3 ). The protein content in the pancreas increased significantly in group FEAA in comparison with group FE.

TABLE 3

The influence of raw or extruded seeds and amino acids on pancreatic parameters in rats $(\mathrm{n}=10)$

\begin{tabular}{lcccc}
\hline Item & Diet FR' & Diet FE & Diet FRAA & Diet FEAA \\
\hline Pancreas, \% BW & $0.31 \pm 0.03$ & $0.34 \pm 0.05$ & $0.35 \pm 0.07$ & $0.36 \pm 0.07$ \\
Trypsin activity, & & & & \\
U/l00 g protein & $4065 \pm 581$ & $5255 \pm 1010$ & $4146 \pm 1217$ & $4999 \pm 1184$ \\
Protein, mg/organ & $4.85 \pm 0.81^{\mathrm{ab}}$ & $4.03 \pm 0.79^{\mathrm{a}}$ & $4.85 \pm 1.01^{\mathrm{ab}}$ & $5.59 \pm 0.76^{\mathrm{b}}$ \\
\hline
\end{tabular}

a,b means in the rows tagged with different letters differ significantly at $\mathrm{P}<0.05$

1.2.3,4 as in Table 2

Extrusion of seeds and addition of AA to the diet with raw faba bean significantly increased crypt depth, suggesting an increase of proliferative processes in the mucosa epithelium. Villi length, width, as well as thickness of the tunica mucosa significantly increased due to extrusion (Table 4).

TABLE 4

Morphometry analysis of the small intestinc (jejunum) of rats $(n=10)$

\begin{tabular}{lllcc}
\hline Item & Diet FR' & Diet FE $^{2}$ & Diet FRAA $^{3}$ & Diet FEAA \\
\hline Crypt depth, $\mu \mathrm{m}$ & $148 \pm 6^{\mathrm{a}}$ & $161 \pm 6^{\mathrm{b}}$ & $165 \pm 6^{\mathrm{b}}$ & $160 \pm 6^{\mathrm{b}}$ \\
Villi length, $\mu \mathrm{m}$ & $368 \pm 15^{\mathrm{a}}$ & $394 \pm 15^{\mathrm{ab}}$ & $376 \pm 12^{\mathrm{a}}$ & $401 \pm 15^{\mathrm{b}}$ \\
Villi width, $\mu \mathrm{m}$ & $101 \pm 3^{\mathrm{a}}$ & $117 \pm 6^{\mathrm{bc}}$ & $114 \pm 6^{\mathrm{ab}}$ & $122 \pm 6^{\mathrm{c}}$ \\
Thickness of tunica mucosa, $\mu \mathrm{m}$ & $537 \pm 18^{\mathrm{a}}$ & $563 \pm 18^{\mathrm{b}}$ & $532 \pm 12^{\mathrm{a}}$ & $576 \pm 15^{\mathrm{b}}$ \\
\hline
\end{tabular}

a.b,e means in the raws tagged with different letter differ significantly at $\mathrm{P}<0.05$ and $\mathrm{SD}$ $1,2,3,4$ as in Table 2

Total culturable bacterial counts decreased $(\mathrm{P}<0.05)$ in group FEAA in comparison with group FRAA, but there was no difference $(\mathrm{P}>0.05)$ in $E$. coli counts between groups (Table 5). 
TABLE 5

Microbiological parameters of the jejunum of rats $(n=7)$

\begin{tabular}{lccc}
\hline Diets & $\begin{array}{c}\text { Total culturable bacterial count } \\
\log \mathrm{CFU}^{* / g}\end{array}$ & $\begin{array}{c}\text { E. coli } \\
\log \text { CFU/g }\end{array}$ & $\begin{array}{c}\text { E. coli/total culturable } \\
\text { bacterial count }\end{array}$ \\
\hline FR $^{1}$ & $5.54 \pm 0.77^{\mathrm{b}}$ & $2.16 \pm 1.84$ & 0.390 \\
FRAA $^{3}$ & $5.09 \pm 0.17^{\mathrm{b}}$ & $1.74 \pm 1.27$ & 0.342 \\
FEAA $^{4}$ & $4.16 \pm 1.11^{\mathrm{a}}$ & $1.23 \pm 0.60$ & 0.296 \\
\hline
\end{tabular}

* CFU - colony forming unit

a.b means in the rows tagged with different letter differ significantly at $\mathrm{P}<0.05$

$1.3,4$ as in Table 2

\section{DISCUSSION}

Extrusion of faba bean seeds at $160^{\circ} \mathrm{C}$ eliminated about $72 \%$ of trypsin inhibitor activity and total hemagglutination activity towards human RBC. Similar effects of extrusion (Kostyra et al., 1999) or boiling (Leontowicz et al., 1998) of faba bean and pea seeds have been observed. Soyabean seeds are less sensitive to extrusion at the same temperature than faba bean (Leontowicz et al., 200la). Sulphur AA $(0.3 \%)$ significantly improved performance of rats fed both raw or extruded faba bean seeds, which is in agreement with other studies. The lack of a positive effect of extrusion of faba bean on digestibility parameters and body gain results from its lower ANF activity or possible negative effects of temperature on lysine and protein availability. Also AA supplementation did not increase pancreatic trypsin activity ( $P>0.05)$, which was reported by Friedman (1994).

Lower lectin activity in raw faba bean and lower $E$. coli number in the rat jejunum caused less significant morphological changes in the small intestine than in rats fed on raw soyabean (Leontowicz et al., 2001a) or pea (Leontowicz et al., 2000). Elimination of lectin activity during extrusion of faba bean seeds and AA supplementation significantly improved intestinal crypt depth, villi length and width.

\section{CONCLUSIONS}

Extrusion of faba bean seeds $\left(160^{\circ} \mathrm{C}\right)$ completely eliminates lectin activity, but TI activity only partially. Rat performance is not affected by extrusion but is significantly improved by amino acid supplementation of both raw and extruded seeds. A synergistic effect of extrusion and amino acid supplementation is observed in respect to feed intake. Both extrusion and amino acid supplementation improve morphological parameters of the small intestine (jejunum). 


\section{EXTRUDED FABA BEANS FOR RATS AND JEJUNUM PARAMETERS}

\section{REFERENCES}

Erlanger B.F., Kokowsky N., Cohen W., 1961. The preparation and properties of two new chromogenic substrates of trypsin. Arch. Biochem. Biophys. 95, 271-278

Friedman M., 1994. Improvement in the safety of foods by SH-containing amino acids and peptids. A review. J. Agr. Food Chem. 42, 3-20

Griffiths D.W., Moseley G., 1980. The effect of diets containing field beans of high or low polyphenolic content of the activity of digestive enzymes in the intestines of rats. J. Sci. Food Agr. 31, 255259

Kostyra H., Kostyra E., Krawczuk S., Leontowicz H., 1999. Influence of extrusion of sced lectins on their haemagglutination proportics. Cost 98 European Commission. 6, 55-59

Leontowicz H., Leontowicz M., Kostyra H., Gralak M.A., Kulasek G.W., 1999. The influence of extrusion or boiling on trypsin inhibitor and lectin activity in leguminous seeds and protein digestibility in rats. Pol. J. Food Nutr. Sci. 8, 77-87

Leontowicz H., Leontowicz M., Biemat M., Gralak M.A., Krzemiński R., Czerwiński J., 2000. The effect of pea lectins on pancreas and jejunum in rats fed semipurified diet. Effects of antinutrients on the nutritional value of legume diets. Cost 98 European Commission. 9, 111-115

Leontowicz H., Leontowicz M., Bienat M., Gralak M.A., Kostyra H., Czerwiński J., 2001 a. The influence of feeding, raw vs extruded soyabean supplemented or unsupplemented with sulphur amino acids on performance, pancretic trypsin activity and morphological parameters of their jejunum in rats. J. Anim Feed Sci. 10, Suppl. 2, 315-321

Leontowicz H., Leontowicz M., Kostyra H., Kulasek G., Gralak M.A., Krzemiński R., Podgurniak M., 2001b. Effects of raw or extruded legume seeds on some functional and morphological gut parameters in rats. J. Anim. Feed Sci. 10, 169-183

Liener I.E., 1994. Implications of antinutritional components in soyabean foods. Crit. Rev. Food Sci. Nutr. 34, 31-67

Lowry O.H., Rosebrough A.L., Farr A.J., Randal R.J., 1951. Protein measurement with the folin phenol reagent. J. Biol. Chem. 193, 265-275

Paredes-Lopez O., Guevara-Lara F., Schevenin-Pindeo M.L., Montes-Rivera R., 1989. Comparison of procedure to determine protein content of developing bean seeds (Phaseolus vulgaris). Plant Food Hum. Nutr. 39, 137-148

Valdebouze P., Bergeron E., Gaborit T., Delort-Luval J., 1980. Content and distribution of trypsin inhibitors and heamagglutinins in some tegume seeds. Can. J. Plant Sci. 60, 695-701 


\section{STRESZCZENIE}

Wpływ ekstruzji nasion bobiku i dodatku aminokwasów siarkowych na wzrost, aktywność trypsyny w trzustce i morfologię jelita czczego szczurów

Badano wpływ ekstruzji nasion bobiku oraz dodatku do diety aminokwasów siarkowych (AA) na aktywność inhibitorów trypsyny (TI) i lektyn, histologię i mikrobiologię jelita czczego szczurów. Szczury Wistar karmiono półsyntetycznymi dietami zawierającymi $10 \%$ nasion bobiku: surowych lub ekstrudowanych ( $w$ temp. $160^{\circ} \mathrm{C}$ ) bez lub z dodatkiem $0,3 \%$ aminokwasów siarkowych (met + cys, 1:1). Ekstruzja obniżała aktywność TI z 1,8 (FR) do 0,5 TUI/mg (FE) i całkowicie eliminowała aktywność aglutynacji określaną względem ludzkich erytrocytów. Ekstruzja nie wpływała na wzrost i wykorzystanie paszy (FER), zwiększała aktywność trypsyny w trzustce (5255 vs $4065 \mathrm{u} / 100 \mathrm{~g}$ białka) i obniżała $(\mathrm{P}<0,05)$ strawność suchej masy $(89,7$ vs $92,9 \%)$. Dodatek AA siarkowych poprawiał przyrosty m.c. i FER zarówno w grupach otrzymujących surowe jak i ekstrudowane nasiona bobiku. Zarówno ekstruzja jak i dodatek AA siarkowych powodowały istotne pogłębienie krypt oraz wydłużenie i pogrubienie kosmków jelita czczego. 